\title{
Sex and obscenity in medieval art
}

\author{
Lesley Smith
}

\section{Contemporary evidence}

When researching early or 'forbidden' historical subjects it can be a considerable challenge finding primary sources that give a first-hand experience of contemporary events. In some periods, such as post-Roman, there is very little documented evidence, to the point where we only know of the existence of some kings purely from coins.

In social groups where an inability to read and write produced virtually no first-hand documentation, we often rely on the notes of doctors or courts. Women were very rarely taught to read - never mind write - until the 18th century. There are exceptions that light up the past with their first-hand experiences of life, and often love, but these gems are fragmented and rare.

All is not lost, however, to the researcher who is prepared to do some lateral thinking, as there are other forms of contemporary evidence in the form of paintings, sculpture and needlework. Many of these were produced by artisans who were 'unlatined', but their evidence is every bit as important as 'official' documents of the day and often much more thrilling.

An example of this is the 'Sheela-na-gig', a shocking, immediately noticeable figure found in Celtic and medieval stonework. 'Sheela' is most commonly depicted as a squat, ugly female creature using her hands to display grotesquely large genitals (Figure 1). These well-known sexual idioms were sometimes perceived as threatening but more often were a symbol of fruitfulness. Many 'Sheelas' seem to be almost Roman goddess-like, as if the physical presence of such an image could cause an effect.

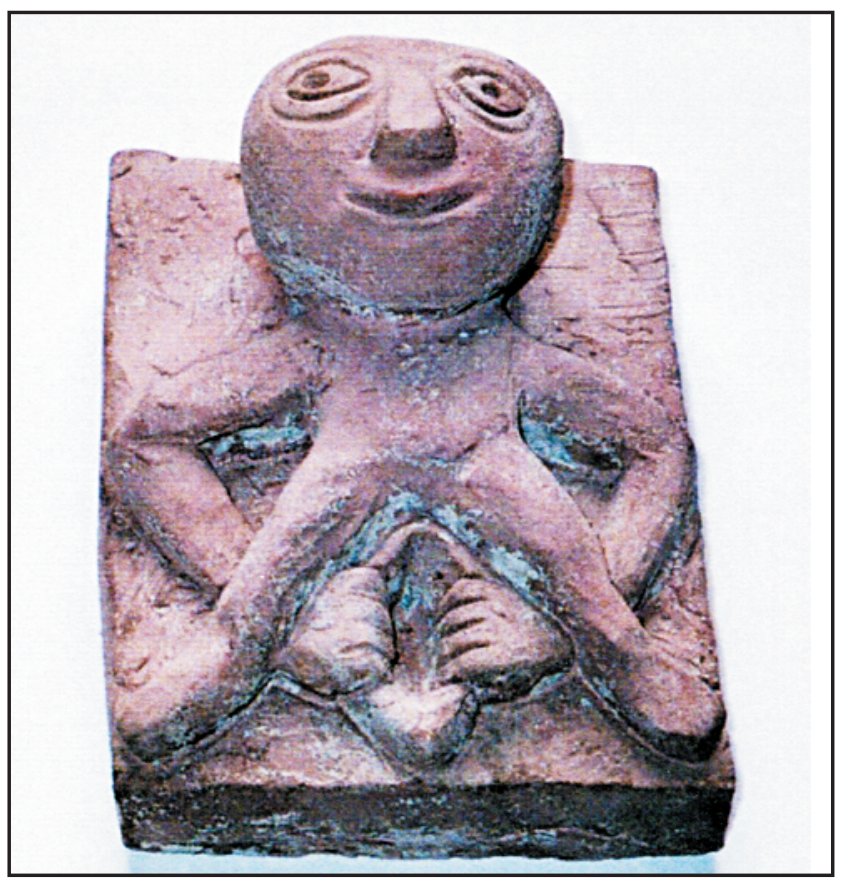

Figure 1 Example of a 'Sheela-na-gig', a shocking figure found in Celtic and medieval stonework. Photograph author's own

J Fam Plann Reprod Health Care 2009; 35(1): 65-66

Tutbury Castle, Tutbury, UK

Lesley Smith, Curator

Correspondence to: Lesley Smith, Tutbury Castle, Tutbury, Staffordshire DE13 9JF, UK. E-mail: info@tutburycastle.com
The more 'forbidden' elements of society can often be found in glorious colour and three-dimensional obscene detail far up in roof tops, where the artist never expected that the masturbating demon or full-breasted nun could be seen from the floor far below. A rooftop tour of some cathedrals, palaces and great halls can be quite an eyeopener - rivalling any current risqué television programme - if you bring with you a pair of binoculars to look inside, rather than out, of the building.

Pictures of hell and other biblical horror stories allowed the artist to produce scenes of the most extraordinary sexual depravities on walls and ceilings. These paintings were held up as a dreadful warning to the sinner, and were in stark contrast to the peaceful harp-playing angels within the paradise for the pure. The only problem is that for quite a number of observers, hell looked rather more fun then an endless music concert in the setting of 'garden open day'. I am sure the artist was aware that his work would produce shocked crowds who would be appalled for long periods of time and perhaps come back the next day to be appalled once again. Wealth through trade brought more social mobility in the 14th century which, in turn, brought crowds, and their silver, to towns competing for attention, and there is no doubt that titillating art forms would bring in the audiences.

\section{Allegorical imagery}

Sexual desire is often locked in layers of allegorical imagery. Some are obvious, for example, a purse is also a scrotum, whilst mermaids are one symbol for a prostitute. Roses, with their folds of petals, appear frequently as a vagina, whilst erect penis swords and poles are seen thrust between the legs of statues or doorframes or in tree knots. A decorated poem may show virginity as a far-off castle containing a maiden peering through her window, with chamber after chamber having closed doors. As the poem progresses, the illustrator may show some of the doors open. This is subtler than it sounds as that image, perhaps carved in wood or carefully painted, may be part of a marvellous myriad landscape of human life. Those readers familiar with the extraordinary works of Hieronymus Bosch may know the triptych known as the 'Garden of Earthly Delights' showing sensual and erotic love at many levels.

Sexual imagery could include everyday objects, including weaponry. 'Bollock' daggers look exactly that: a sharp blade topped with a pair of wooden testicles as a handle. Aristotle's orgasm described as "a little death" came to full fruition in these daggers.

\section{Jewellery and clothing}

Jewellery and pilgrim pins to be worn on hats or dangling from bodices could be positively pornographic. I have a hatpin of a vagina riding on the back of a horse. The vagina is crowned and is a reference to the king of the day, possibly Richard II. I also have a small penis plus testicles, in pewter, that can be worn as a ribald joke item dangling from the wrist cuff (Figure 2).

The art of the dressmaker drew in tight waists, exposed breasts or made nipple patterns on stomachers whilst men strutted around in huge codpieces, and in mediaeval times some very tight hose indeed was in evidence that revealed the wearer's full shape right up the waist.

Bare buttocks above dropped trousers poke out from ceiling corners and at the top of pillars carved in wood and 


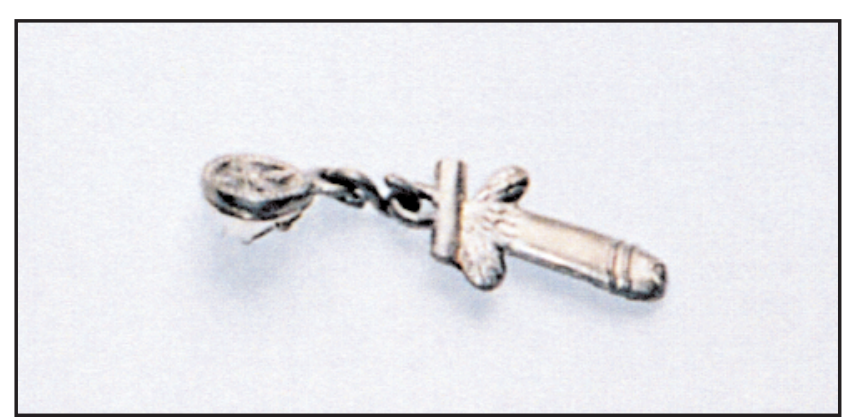

Figure $2 \mathrm{~A}$ small penis plus testicles made of pewter that can be worn dangling from the wrist cuff. Photograph author's own

stone and even on the edge of some seats in church. Great fun, when you know what you are looking for and if you consider that some Christian services lasted for 3 hours and people were obliged to attend. Perhaps these artisans were offering a humorous service too?

\section{Symbols of desire}

During the frustrating medieval days of 'Courtly Love' the man and woman were supposed to pine and wax lyrical, being able only to glance at those they desired without ever touching, except perhaps in a dance. This concept of pure knights and sighing damsels had cult status in England at one time in honour of the legend of King Arthur and also became fashionable in foreign courts such as in France. The result was a large quantity of art born out of pure frustration and no doubt given to those desired as a symbol of unrequited love. Many of these pieces tell passionate tales with black humour, such as the chest made in Berne in Switzerland showing a woman grating a man's heart and another with a man covered in arrow quills as if martyred by a woman's rejection of him.

What we can't tell is if the artisans concerned were briefed in each case by the client or if they interpreted the passion and sexual desire of humanity. What is sure, however, is that these relics from the past tell brilliant and colourful tales of real lives: the lives of our ancestors in all their ribald glory.

\section{Acknowledgements}

The author would like to thank the following individuals for their help and advice: Professor R Arnott, Director of the Centre for the History of Medicine, University of Birmingham Medical School, Birmingham and Dr G Williams, British Museum, London, UK.

\section{Bibliography}

1 Camille, Michael. The Medieval Art of Love: Objects and Subjects of Desire. London, UK: Laurence King Publishing, 1998.

2 McDonald, Nicola (ed.). Medieval Obscenities. York, UK: York Medieval Press, 2006.

3 Haynes, Alan. Sex in Elizabethan England. Stroud, UK: Sutton Publishing Ltd, 1997.

4 Herman, Eleanor. Sex With Kings. New York, NY: Harper Collins Publishers, 2004.

\section{About the Author}

Lesley Smith is currently a postgraduate student in the Centre for the History of Medicine of the University of Birmingham, where she is developing a $\mathrm{PhD}$ in obstetrics and gynaecology in early modern Britain. She holds an honorary degree for "services to history". She makes 200-300 public appearances a year and also works as a TV historian in the UK and abroad including the USA. Lesley is also Curator of Tutbury Castle and is currently involved with a major research project with the British Museum, which is her excuse for why it is taking her so long to finish her $\mathrm{PhD}$ !

\section{MEETINGS AND COURSES}

30 January 2009

Title: 4th Annual Scientific Meeting of BASHH and the FSRH: "Building Bridges and Forging Relationships". Venue: RCOG, London, UK. Details: Topics include: sexual behaviour in young people; updating on HPV and the chlamydia national screening programmes. Accreditation: FSRH and RCP applied for. Information: Cathy Taylor, Conference Office, c/o Palm Training Ltd, 6 Foinavon Close, Rowley Regis, West Midlands B65 8QB. UK. Tel: +44 (0) 1384 235207. E-mail: palmtraining@tesco.net.

\section{March 2009}

Title: Northern Interbranch - Spring Update. Venue: Holiday Inn, Wakefield Road, Garforth, Leeds LS25 1LH, UK. Details: Speakers: Dr John Lee - Men's bits \& bobs: some diagnostic and management challenges; Dr Sue Stillwell Informed consent for IUD/S fitting: are we getting it right? and Dr Okimyomibo Graham - Cultural and religious beliefs: impact on sexual and reproductive health care. Accreditation: 1 hour IUD/S, 3 hours. Information: Dr Jennifer Manuel, 28 The Spinney, Moortown, Leeds LS17 6SP, UK. E-mail: jennifer.manuel@nhs.net.

\section{March 2009}

Title: North West Society of Sexual and Reproductive Health Care. Venue: The Centre, Birchwood, Warrington, UK. Details: 10.00am-4.00pm. Morning session: an update on intrauterine contraception, chlamydia screening, osteoporosis and long-acting progestogens. Afternoon session: psychosexual medicine: an interactive session. Accreditation: FSRH applied for. Information: Mrs Linda Sloan, Course Organiser, 5 Redhouse Lane Eccleston, Chorley, Lancs PR7 5RH. UK. Tel: +44 (0) 1257453665. E-mail: lindasloan5@btinternet.com.
11-13 March 2009

Title: DFSRH Theory Course organised by Kirkcaldy \& Levenmouth Community Health Partnership. Details: See display advertisement on page 67.

\section{7-29 April 2009}

Title: DFSRH Course. Venue: London, UK Details: A 3-day course suitable for doctors wishing to obtain the Diploma of the FSRH (of the RCOG). The course is also suitable for updating family planning doctors. Accreditation: FSRH applied for. Information: Grace Gray, Training Administrator, Sexual \& Reproductive Health Training Partnership, Southwark PCT, Artesian Health Centre, 138 Grange Road, Bermondsey, London SE1 3GF, UK. Tel: +44 (0) 203049 7949. Fax: +44 (0) 203049 7940. E-mail: srhtp@southwarkpct.nhs.uk.

\section{1-12 May 2009}

Title: Loc Med. Venue: Welsh Institute for Women's Health, Cardiff Medicentre, Heath Park, Cardiff, UK. Details: Applications are invited from Diplomates of the Faculty of Sexual and Reproductive Health who are actively involved in contraception and reproductive health care, equivalent to 100 sessions in the past year. Accreditation: MEd09/02. Information: Mrs Deborah Jenkins, Welsh Institute for Women's Health, Cardiff Medicentre, University Hospital of Wales, Heath Park, Cardiff CF14 4UJ, UK. Tel: +44(0) 292075 8587. E-mail: wiwhdeb@ btinternet.com

\section{May 2009}

Title: Update in Women's Health. Venue: Centre for Life, Times Square, Newcastle upon Tyne. NE1 4EP, UK. Details: Open to all doctors, nurses and health care staff working in or with an interest in contraception. Accreditation: FSRH applied for
(6 hours). Information: Dr Margaret Hogarth or Mrs Deborah Crudace, Newcastle Contraception and Sexual Health Service, Newcastle General Hospital, Westgate Road, Newcastle upon Tyne NE4 6BE, UK. Tel: +44 (0) 191219 5239. Fax: +44 (0) 191219 5232. E-mail: margaret. hogarth@newcastle-pct.nhs.uk or deborah. crudace@newcastle-pct.nhs.uk.

\section{1-22 May 2009}

Title: FSRH Annual Scientific Meeting. Details: See display advertisement on page 68

\section{6-19 May 2009}

Title: 8th European Menopause Conference. Details: See advertisement on inside back cover.

\section{2-24 June 2009}

Title: DFSRH Course. Venue: London, UK Details: A 3-day course suitable for doctors wishing to obtain the Diploma of the FSRH (of the RCOG). The course is also suitable for updating family planning doctors. Accreditation: FSRH applied for. Information: Grace Gray, Training Administrator, Sexual \& Reproductive Health Training Partnership, Southwark PCT, Artesian Health Centre, 138 Grange Road, Bermondsey, London SE1 3GF, UK. Tel: +44 (0) 203049 7949. Fax: +44 (0) 203049 7940. E-mail: srhtp@southwarkpct.nhs.uk.

\section{1-3 July 2009}

Title: DFSRH Theory Course. Venue: Britannia Stadium, Stanley Matthews Way, Stoke on Trent ST4 4EG, UK. Accreditation: DFSRH Modules 1-6 applied for. Information: Michelle Broomhall, Medical Secretary, Piccadilly Centre, 59 Piccadilly, Hanley, Stoke on Trent ST1 1HR, UK. Tel: +44 (0) 1782 425962. Fax: +44 (0) 1782 425965. E-mail: Michelle.Broomhall@stoke. nhs.uk. 